\title{
Prevalence of Theileria equi among Horses Based on Parasitological and Universal Molecular Technique
}

\author{
T.M. Vidhyalakshmi ${ }^{1 *}$, Sunant K. Raval $^{1}$, Bharat B. Bhanderi ${ }^{2}$ and Amit K. Kanani ${ }^{3}$ \\ ${ }^{1}$ Department of Veterinary Medicine, ${ }^{2}$ Department of Veterinary Microbiology, College of \\ Veterinary Science and Animal Husbandry, Anand Agricultural University, \\ Anand, Gujarat, India \\ ${ }^{3}$ Animal Disease Investigation Office, Ahmedabad, Gujarat, India
}

*Corresponding author

\section{A B S T R A C T}

\begin{tabular}{|c|c|}
\hline Keywords & $\begin{array}{l}\text { Equine theileriosis, being an OIE listed disease mainly requires frequent disease screening } \\
\text { and monitoring. The aim of the present study was to monitor the prevalence of theileriosis }\end{array}$ \\
\hline $\begin{array}{l}\text { Blood samples, Equine } \\
\text { merozoite antigen, } \\
\text { Polymerase chain } \\
\text { reaction, Prevalence, } \\
\text { Theileria equi }\end{array}$ & $\begin{array}{l}\text { in horses by using both parasitological method and molecular diagnostic technique based } \\
\text { on Equine Merozoite Antigen- } 5 \text { and } 6 \text {. In the present study, samples from } 248 \text { horses were } \\
\text { collected randomly. Positive samples detected by using Giemsa stained blood smear } \\
\text { technique (GSBT) were used as the positive control samples for screening randomly }\end{array}$ \\
\hline Article Info & \\
\hline $\begin{array}{l}\text { Accepted: } \\
04 \text { September } 2018 \\
\text { Available Online: } \\
10 \text { October } 2018\end{array}$ & $\begin{array}{l}\text { DNA, } 30 \text { were positive indicating an overall prevalence rate of } 12.10 \% \text { by universal PCR } \\
\text { whereas GSBT revealed only } 5.05 \% \text { prevalence. This study emphasized the usefulness of } \\
\text { universal PCR technique as an efficient diagnostic tool for determination of } T \text {. equi in field } \\
\text { samples rather than Giemsa stained blood smear technique. }\end{array}$ \\
\hline
\end{tabular}

\section{Introduction}

Equine theileriosis caused by Theileria equi is an OIE listed tick transmitted hemoprotozoan disease with worldwide socio-economic impact on horse industry. Theileria equi (Previously known as Babesia equi, later reclassified as Theileria equi (Ibrahim et al., 2011; Mehlhorn and Schein, 1998) is the causative agent of equine theileriosis which occurs in tropical and subtropical regions of the world. Being an endemic disease in Asia, Southern Europe, Latin America and Africa
(Ristic, 1988), long-term monitoring of the prevalence of infection is very important in these areas. The disease has been reported by more than 20 countries of the world and the prevalence study results are found to be varying depending upon the study design, sample size and diagnostic techniques used. Equine piroplasmosis is among the listed diseases of the World Organization for Animal health (OIE), notifiable within 72 hours. Long-term monitoring of the prevalence of infection therefore is very important in areas where the disease has been reported, given the 
international importance of the disease and the potential impact on the horse industry. So the knowledge of the prevalence of infection is essential to set up efficient control measures.

Equine theileriosis is a challenge as the parasitemia often remains very low and the infected horses may act as the lifelong nucleus for spreading the disease through vector ticks, thereafter the outbreak or re-emergence of the disease (Wise et al., 2013). The latently infected horses may exhibit poor performance following physical, immunological or mental stress and may predispose horses to the clinical manifestation of the disease and death. But the clinical signs of equine theileriosis are variable and non-specific making the diagnosis difficult (Chhabra et al., 2012). So it is important to identify infected and noninfected horses based on more sensitive and specific diagnostic tool, thus to prevent the spread of the disease among the susceptible equine population by appropriate preventive and control measures.

The aim of the present study was PCR based unravelling of prevalence of equine theileriosis by targeting the equine merozoite antigen (EMA-5 and EMA-6) which may contribute well to the future diagnostic as well as therapeutic approaches in cases of equine theileriosis. In the present study, Polymerase chain reaction as well as microscopic methods was compared in which PCR, being molecular diagnostic technique determines the actual presence of parasitic DNA for confirmation of horses as a latent carrier of T. equi infection.

\section{Materials and Methods}

\section{Sample collection}

A total of 248 working as well as racing horses of all ages, regardless of sex and breed were included in the study for screening theileriosis by using PCR technique. The study was carried out for a period of nine months and blood samples were collected for Giemsa stained blood smear examination as well as for extraction of DNA of $T$. equi by using universal polymerase chain reaction. Consent from the owners of the horses was obtained for sample collection and the blood samples were collected as per the standard procedure without any stress or harm to the horses.

\section{Giemsa stained blood smear examination}

Giemsa staining technique was used for microscopical detection of T.equi in blood smears. Thin blood smears of 248 horses, prepared by using freshly collected blood samples were allowed to dry and fixed in methanol for 1 minute. Giemsa stain was flooded on these slides for 30-35minute followed by washing under the running tap water and dried for examination under oil immersion microscopy.

\section{Extraction of genomic DNA of T. equi from whole blood}

Blood samples collected from 248 horses into sterile $\mathrm{K}_{3}$ EDTA vials were stored at $-20^{\circ} \mathrm{C}$ until used for DNA extraction. Genomic DNA of $T$. equi was extracted from whole blood samples by using commercially available QIAamp-DNA extraction blood mini kit (CATALOG NO.51106). Spin protocol was used for the purification of the genomic DNA from whole blood by using a microcentrifuge DNA extraction was carried out according to the instruction manual of QUIAamp DNA blood mini kit (Quiagen, Germany).

\section{Quantification of DNA}

The DNA was quantified by using nanodrop spectrophotometer (Eppendorf Thermofisher) and stored at $-20^{\circ} \mathrm{C}$ until use for PCR. 


\section{Primers}

DNA of Theileria equi was amplified by using PCR where the primer sequences used were Forward (EMA-5) 5'TCGACTTCCAGTTGGAGTCC-3' and Reverse (EMA-6) 5'AGCTCGACCCACTTATCAC-3' (Battsetseg et al., 2001) yielding a 268bp product.

\section{PCR protocol}

All PCR reactions were performed in $19 \mu$ lof reaction mixture consisting of $10 \mu \mathrm{l}$ Master mix, $2 \mu \mathrm{l}$ of each forward and reverse primer, $2.5 \mu \mathrm{l}$ of Millique water and $6 \mu \mathrm{l}$ of extracted DNA.PCR reactions also included a negative control, consisting of the $19 \mu \mathrm{l}$ of reaction mix and $6 \mu \mathrm{l}$ of Millique water. The amplification conditions for $T$. equi included 40 cycles with enzyme activation at $95^{\circ} \mathrm{C}$ for $10 \mathrm{~min}$, denaturation at $94^{\circ} \mathrm{C}$ for $1 \mathrm{~min}$, primer annealing at $60^{\circ} \mathrm{C}$ for $1 \mathrm{~min}$ and amplification at $72^{\circ} \mathrm{C}$ for 1 min followed by final extension at $72^{\circ} \mathrm{C}$ for $5 \mathrm{~min}$. The final PCR products were subjected to electrophoresis in a $1.5 \%$ agarose gel with TBE buffer and DNA bands were visualized by using UV transilluminator or Gel documentation System. Positive samples for $T$. equi detected by using Giemsa stained blood smear technique were used as positive control.

\section{Agarose gel electrophoresis}

Preparation of $2 \%$ agarose gel was done by taking $1 \mathrm{gm}$ of agarose powder into a $250 \mathrm{ml}$ flask and added $50 \mathrm{ml}$ of $0.5 \mathrm{x}$ TBE buffer. The solution was heated in a microwave until agarose was completely dissolved. Gel casting tray was used for casting and appropriate number of comb was placed in gel tray and added $2.5 \mu \mathrm{l}$ of ethidium bromide to the gel. Gel was poured into tray and allowed to cool for 15-30 minutes at room temperature. Later the comb was removed from gel tray and placed in electrophoresis chamber and covered with TBE buffer. Thereafter $1 \mu \mathrm{l}$ of 1oading dye was added to a $6 \mu \mathrm{l}$ PCR product and mixed well and loaded. About 2-3 $\mu$ l of standard (Ladder) or $3 \mu$ positive control was loaded in another well and electrophoresis was done at $80 \mathrm{~V}$ for 30 minutes.

Finally DNA bands were visualized using UV transilluminator or Gel documentation System.

\section{Results and Discussion}

\section{Parasitological method}

Examination of the stained blood smears revealed few parasitized red blood cells with T.equi and shown in Figure 1. Out of 248 blood smears examined, only 5 were found to be positive indicating a prevalence rate of $2.02 \%$ indicating a low sensitivity when compared to PCR.

\section{Polymerase chain reaction}

Out of 248 horse samples screened for T. equi DNA by using Universal PCR technique and gel electrophoresis, 30 were found to be positive indicating an overall prevalence rate of $12.10 \%$. Out of 30 horses positive for $T$. equi as detected by PCR based on EMA-5 and EMA-6, only 13 horses have shown varying clinical symptoms whereas rest of 17 horses positive for theileriosis were found to be apparently healthy. DNA extracted from 248 blood samples were amplified and shown in Figure 2.

The present study revealed low sensitivity of Giemsa stained blood smear examination technique to detect low level of parasitemia or subclinical or carrier status when compared to the PCR technique therefore supporting observations of other studies (Bahrami et al., 
2014; Moatloang et al., 2008; Rampersad et al., 2003). Rampersad et al., (2003) observations consists of seroprevalence of $T$. equi as $9.5 \%$ positive by Giemsa stained blood smear examination technique, whereas 15.24\% by PCR technique (Rampersad et al.,
2003). Bahrami et al., (2014) shows the seroprevalence of $T$. equi as $4.76 \%$ positive by Giemsa stained blood smear examination technique, whereas $22.86 \%$ by PCR (Bahrami et al., 2014).

Fig.1 Giemsa stained blood smear positive for T. equi

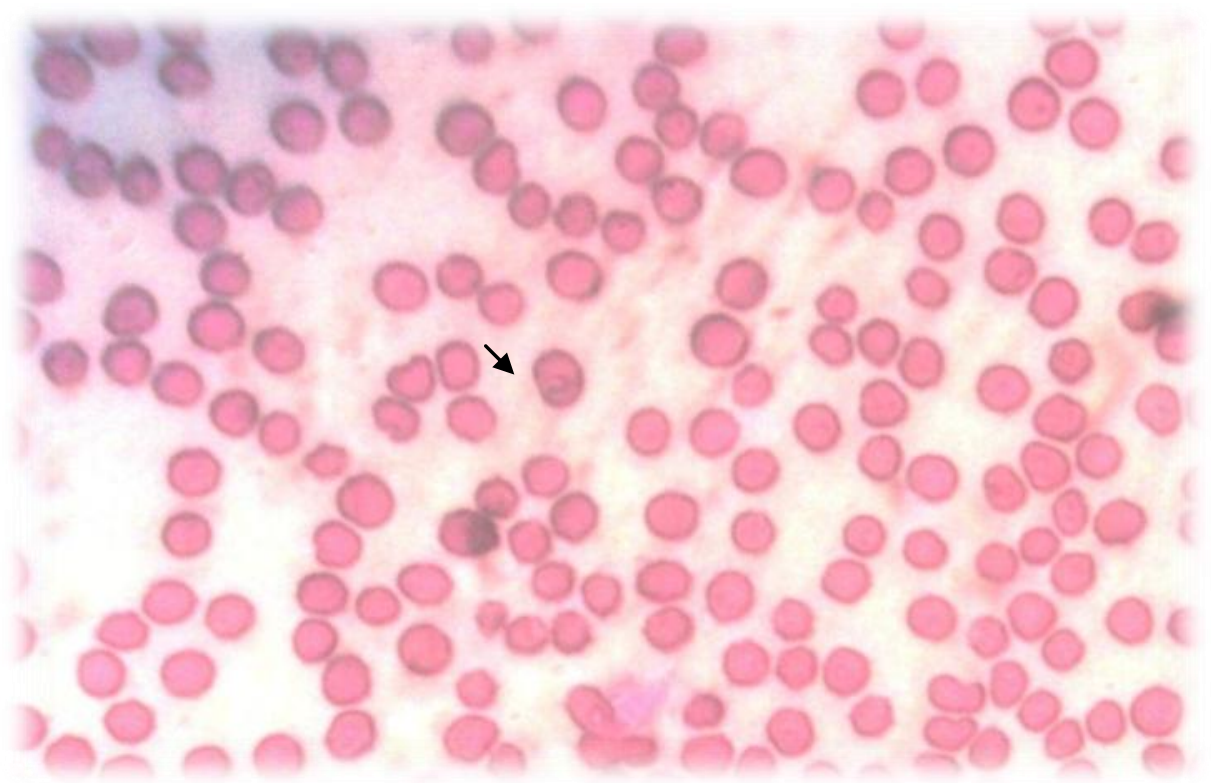

Fig.2 Agar gel electrophoresis revealing PCR product of 268 bp positive for T. equi

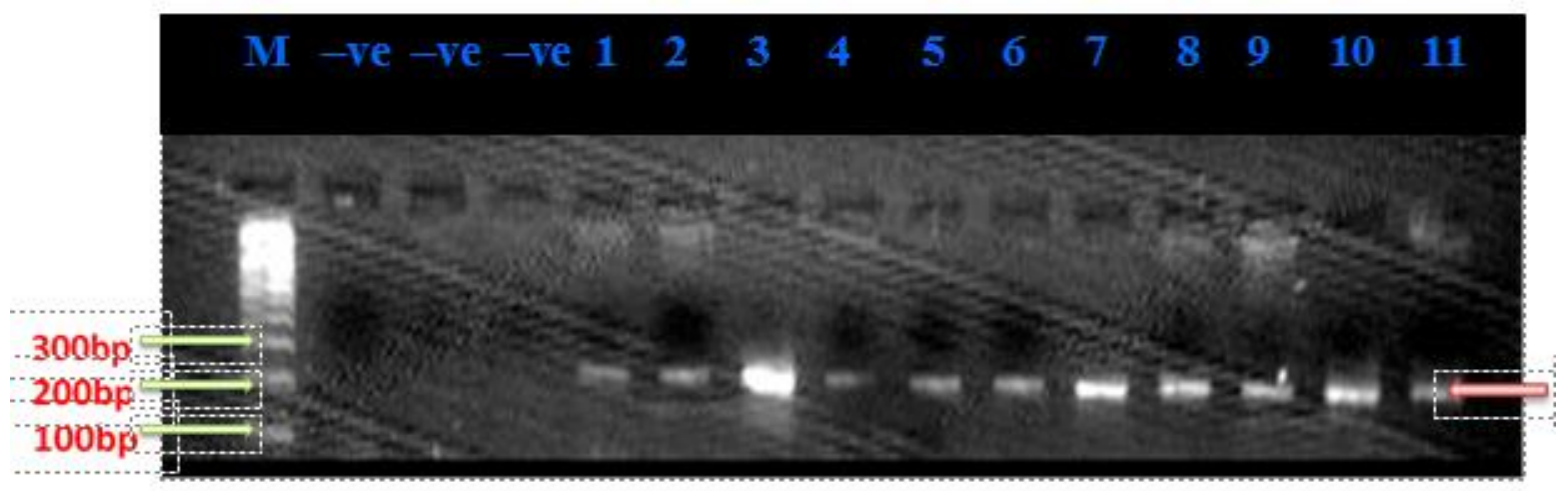

LANE M: Molecular weight ladder

LANE -VE: Negative controls

LANE-1 to 11: PCR product of field samples positive for T. equi

Even though, molecular and serological techniques give more dependable tools for diagnosis of equine piroplasmosis (Salim et al., 2008), the previous reports shows higher prevalence rate (Khurana et al., 2014) based on the fact that most of the serological techniques provide the prevalence status depending on the circulating antibodies, not 
necessarily the antigen, which may be detected even in horses with a past history of positivity for $T$. equi infection (Bruning, 1996). In the present study, PCR technique is used to detect $T$. equi DNA based on Equine merozite antigen-5 and 6 and found to be more sensitive than microscopic methods (Bruning, 1996; Ibrahim et al., 2011; Malekifard et al., 2014) and specific than serological methods (Ibrahim et al., 2011; Tenter and Friedhoff, 1986).

In conclusions, the present study revealed the prevalence of theileriosis among the horse population based on EMA-5 and EMA-6 antigen of $T$. equi by using universal molecular technique and the same is found to be more dependable diagnostic tool than microscopic method as the former detects circulating parasitic DNA. Thus present study revealed the efficiency of molecular technique for monitoring Theileriosis among horses. Therefore universal PCR technique may be helpful to develop better strategies to minimise the likelihood of clinical cases or outbreaks of theileriosis in horses of endemic areas under the circumstances of existing challenge in complete elimination of theileriosis. Priority should be given for the development and validation of highly sensitive, simple and specific diagnostic tool to distinguish infected and non-infected horses.

\section{Acknowledgements}

This work was supported by faculty of Veterinary Medicine and Veterinary Microbiology, College of Veterinary Science and Animal Husbandry, Anand.

\section{References}

Bahrami, S., Ghadrdan, A. R., Mirabdollahi, S. M. and Fayed, M. R. (2014). Diagnosis of subclinical equine theileriosis in centre of Iran using parasitological and molecular methods. Trop Biomed. 31: 110-117.

Battsetseg, B., Xuan, X., Ikadai, H., Bautista, J. L. R., Byambaa, B., Boldbaatar, D., Batturd, B., Battsetseg, G., Batsukh, Z., Igarashi, I., Nagasawa, H., Mikami, T. and Fujisaki, K (2001). Detection of Babesia caballi and Babesia equi in Dermacentor nuttalli adult ticks. Int. J. for Parasitol. 31: 384-386.

Bruning, A. (1996). Equine piroplasmosis an update on diagnosis, treatment and prevention. Br. Vet. J. 152: 139-151.

Chhabra, S., Ranjan, R., Uppal, S. K. and Singla, L. D. (2012). Transplacental transmission of Babesia equi (Theileria equi) from carrier mares to foals. J.Parasit. Dis. 36: 31-33.

Ibrahim, A. K., Gamil, I. S., Abd-El baky, A. A., Hussein, M. M. and Tohamy, A. A. (2011). Comparative Molecular and Conventional Detection Methods of Babesia equi in Egyptian Equine. Global Veterinaria. 7: 201-210.

Khurana, S. K., Singh, B. K., Yadav, S. C., Gulati, B. R., Malik, P., Kumar, R., Virmani, N., Kumar, S., Barua, S., Vaid, R. K., Manuja, A., Dedar, R. and Singha, H. (2014). Surveillance, monitoring and control of existing and emerging diseases of equines. National Research Centre on Equines (NRCE), Annual Report (2013-2014). Hisar-125 001, India, pp.26.

Malekifard, F., Tavassolil, M., Yakhchali, M. and Darvishzadeh, R. (2014). Detection of Theileria equi and Babesia caballi using microscopic and molecular methods in horses in suburb of Urmia, Iran. Vet. Res. Forum. 5(2): 129 - 133.

Mehlhorn, H. and Schein, E. (1998). Redescription of Babesia equi (Laveran, 1901) as Theileria equi. Parasitol. Res. 84:467-475. 
Moatloang, M. Y., Thekisoe, O. M. M., Alhassan, A., Bakheit, M., Motheo, M. P., Masangane, F. E. S., Thibedi, M. L., Inoue, N., Igarashi, I., Sugimoto, C. and Mbati, P. A. (2008). Prevalence of Theileria equi and Babesia caballi infections in horses belonging to resource-poor farmers in the northeastern free state province, South Africa. Onderstepoort. J. of vet. Res. 75:141-146.

Rampersad, J., Cesar, E., Campbell, M. D., Samlal, M. and Ammons, D. (2003). A field evaluation of PCR for the routine detection of Babesia equi in horses. Vet. Parasitol. 114: 81-87.

Ristic, M., 1988. Babesiosis of Domestic Animals and Man. CRC Press, Boca Raton, FL, USA.
Salim, B. O. M., Hassan, S. M., Bakheit, M. A., Alhassan, A., Igarashi, I., Karanis, P. and Abdelrahman, M. B. (2008). Diagnosis of Babesia caballi and Theileria equi infections in horses in Sudan using ELISA and PCR. Parasitol Res. DOI 10.1007/s00436-008-1108-z.

Tenter, A.M., and Friedhoff, K.T., 1986. Serodiagnosis of experimental and natural Babesia equi and B. caballi infections. Vet. Parasitol. 20, 49-61.

Wise, L. N., Kappmeyer, L. S., Mealey, R. H. and Knowles, D. P. (2013). Review of Equine Piroplasmosis. J Vet Intern Med. 27(6):1334-46.

\section{How to cite this article:}

Vidhyalakshmi, T.M., Sunant K. Raval, Bharat B. Bhanderi and Amit K. Kanani. 2018. Prevalence of Theileria equi among Horses Based on Parasitological and Universal Molecular Technique. Int.J.Curr.Microbiol.App.Sci. 7(10): 318-323. doi: https://doi.org/10.20546/ijcmas.2018.710.033 